\title{
Sirolimus influence on hepatectomy-induced liver regeneration in rats
}

\section{Efeito do sirolimo na regeneração hepática induzida por hepatectomia no rato}

\author{
Edimar Leandro Toderke, TCBC-PR'; Giorgio Alfredo Pedroso Baretta, TCBC-PR; Ozimo Pereira Gama Filho'; Jorge Eduardo \\ Fouto MATIAS, ACBC-PR
}

A B S T R A C T

\begin{abstract}
Objective: To evaluate the influence of sirolimus on liver regeneration triggered by resection of $70 \%$ of the liver of adult rats. Methods: we used 40 Wistar rats randomly divided into two groups (study and control), each group was divided into two equal subgroups according to the day of death (24 hours and seven days). Sirolimus was administered at a dose of $1 \mathrm{mg} / \mathrm{kg}$ in the study group and the control group was given $1 \mathrm{ml}$ of saline. The solutions were administered daily since three days before hepatectomy till the rats death to removal of the regenerated liver, conducted in 24 hours or 7 days after hepatectomy. Liver regeneration was measured by the KWON formula, by thenumber of mitotic figures (hematoxylin-eosin staining) and by the immunohistochemical markers PCNA and Ki-67. Results: there was a statistically significant difference between the $24 \mathrm{~h}$ and the $7 \mathrm{~d}$ groups. When comparing the study and control groups in the same period, there was a statistically significant variation only for Ki-67, in which there were increased numbers of hepatocytes in cell multiplication in the $7 d$ study group compared with the $7 d$ control group $(p=0.04)$. Conclusion: there was no negative influence of sirolimus in liver regeneration and there was a positive partial effect at immunohistochemistry with Ki-67.
\end{abstract}

Key words: Liver regeneration. Sirolimus. Hepatectomy. Proliferating cell nuclear antigen.

\section{INTRODUCTION}

L iver ver regeneration is an event that involves multiple cells and a complex interaction between cytokines and growth factors. Higgins and Anderson ${ }^{1}$ published the first studies on liver regeneration in 1931, when they noticed a remarkable ability of rat the liver to regenerate after partial hepatectomy. This model of hepatectomy with resection of approximately $70 \%$ of the liver mass has been widely used for investigation of liver regeneration ${ }^{2}$. The hepatic regenerative process in rats resembles that of the human liver, which explains the widespread use of this model in many areas of current biomedical research ${ }^{3}$.

Liver regeneration is an essential component in the mechanism of organ protection against the loss of functional liver tissue, either injury, chemical or viral, traumatic loss or partial hepatectomy. In the absence of this regenerative process, morbidity and mortality are often increased ${ }^{4}$.

The liver has the characteristic to proportionally adjust its size to the requirements of the receiver through regenerative capacity, which is crucial for successful living donor liver transplantation, and for those in whom the implanted organ is less than ideal for the recipient organism size ${ }^{5}$.
The phenomenon of liver regeneration is large, complex and not yet fully understood ${ }^{6-9}$. Interferences of drugs, intrinsic metabolism of the organism and diseases are also being studied for the understanding of this complex network of stimulatory and inhibitory factors of liver regeneration.

Sirolimus is a new, potent immunosuppressive drug and $t$ is currently proposed as therapy following liver transplantation to control organ rejection. It acts by blocking the immune response interfering with the production of lymphocytes. It binds to an intracellular protein called FKBP12 complex, which is postulated to be a pathway of response to regenerative stimulus ${ }^{10-14}$. This interference in cell proliferation may cause changes in the phenomenon of liver regeneration. Therefore, we decided to evaluate whether the process of liver regeneration after $70 \%$ liver resection in rats may render new information relevant to clinical practice when under the influence of the immunosuppressant sirolimus.

\section{METHODS}

The study was in accordance with the standards of the Brazilian College of Animal Experimentation (COBEA)

1. Post-Graduation Program in Surgical Clinics, Department of Surgery, Universidade Federal do Paraná - UFPR, Paraná - PR, Brazil. 
and was approved by the Ethics in Research Committee of the Department of Health Sciences, under the CEP/SD record: AN.006.002.07.06.

used 40 adult male Wistar rats (Rattus norvegicus Albinus, Rodentia mammalia), with an average initial weight of $512.06 \mathrm{~g}$ (SD 34.88), ranging from $431.8 \mathrm{~g}$ to $610 \mathrm{~g}$. The rats were kept in a suitable environment and received balanced diet ad libitum. The 40 animals were randomly divided into two groups, control and study, with 20 animals each. The control group was divided into control group $24 \mathrm{~h}\left(\mathrm{CG}_{24 \mathrm{~h}}\right)$, consisting of ten animals that were killed 24 hours after partial hepatectomy, and control group seven days $\left(\mathrm{CG}_{7 \mathrm{~d}}\right)$, with ten animals that were killed seven days after partial hepatectomy; the study group was divided into study group $24\left(\mathrm{SG}_{24 \mathrm{~h}}\right)$ with ten animals that were euthanized 24 hours after partial hepatectomy, and study group seven days $\left(\mathrm{SG}_{7 \mathrm{~d}}\right)$, consisting of ten animals that were killed seven days after partial hepatectomy.

Control group was orally administered $0.9 \%$ isotonic sodium chloride saline (SSI 0.9\%), and the study group, oral sirolimus solution at a dose of $1 \mathrm{mg} / \mathrm{Kg} /$ day. The solutions were administered by gavage process according to daily weighting of the rats, which started three days before partial hepatectomy and was maintained until the day of death of the animals.

The sedation and anesthesia of rats were carried out with isoflurane through a closed vaporizing system, and maintenance of anesthesia in a concentration of 1.5-3\% and oxygen flow ranging from 0.5 to $3 \mathrm{~L} / \mathrm{min}$.

The rats underwent classic $70 \%$ partial hepatectomy, with resection of the left lateral and median lobes after ligation of the vascular pedicle through a small incision in the midline of the abdominal wall ${ }^{1}$.

Euthanasia was induced by inhalation of vaporized isoflurane in hood with medical oxygen. The abdominal incision was reopened and the regenerated liver was removed for analysis.

Liver regeneration was evaluated by the formula proposed by Kwon ${ }^{15}-\%$ regeneration $=(\mathrm{S} \times \mathrm{PH} \times 70) /$ $(P S \times R)$, where $S=$ weight in grams of the resected liver at sacrifice; $\mathrm{PH}=$ the weight of the rat at hepatectomy; PS = weight of the rat at sacrifice; and $R=$ the weight of the resected liver at hepatectomy - which provides a percentage value of regeneration based on body and liver weights of rats at times of hepatectomy and death.

Cell proliferation was assessed by counting cells through mitosis at hematoxylin-eosin staining and by immunohistochemistry, with the use of the cell proliferation markers PCNA and Ki67 16-21.

The study used statistical analysis of the normal (Gaussian) distribution and homoscedasticity of the variances of the variables for the choice of the statistical test. In nonparametric analysis, we used the Mann-Whitney test, and for parametric analysis, the test Student's t test. We used the criteria of Aspin-Welch for calculating the degrees of freedom. In all statistical tests the level of significance was $p<0.05$.

\section{RESULTS}

Liver regeneration evaluated by the Kwon formula showed a statistically significant increase in the remaining liver in both groups during the first 24 hours and on the seventh day after hepatectomy. The comparison between the control and study groups showed no statistically significant variation (Figure 1).

The evaluation of mitotic index by hematoxylineosin (HE) resulted in no statistical difference between 24hour subgroups when compared with the seven-day subgroups. There was no statistically significant difference between the control and study groups in the same period (Figure 2).

Regarding cell proliferation as measured by proliferating cell nuclear antigen (PCNA), there was neither a statistically significant difference between groups, nor between subgroups (Figure 3). When cell proliferation was evaluated by antigen Ki-67, there was no statistical difference between the 24-hour subgroups when compared with seven day subgroups. There was no statistical difference between the control and study groups in 24 hours. However, there was a statistically significant difference between the control and study groups after seven days $(p=0.04)$ (Figure 4).

\section{DISCUSSION}

The rats used in this study were considered to be fully developed, with a weight of over 350 grams. By using adult rats, we analyze the phenomenon of liver regeneration

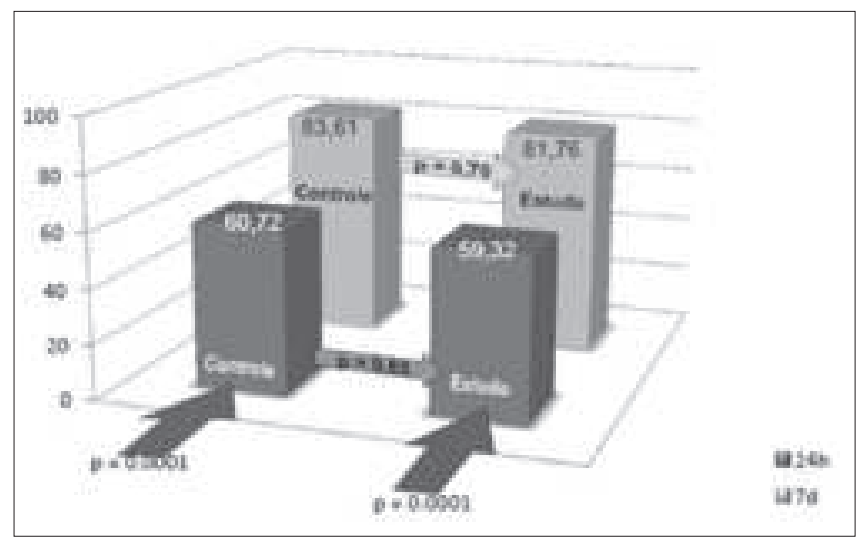

Figure 1 - Evaluation of the percentage of liver regeneration by the Kwon formula. Statistical comparison between the study and control groups at the periods 24 hours (dark grey) and seven days (light grey). Statistical comparison between groups (p). 


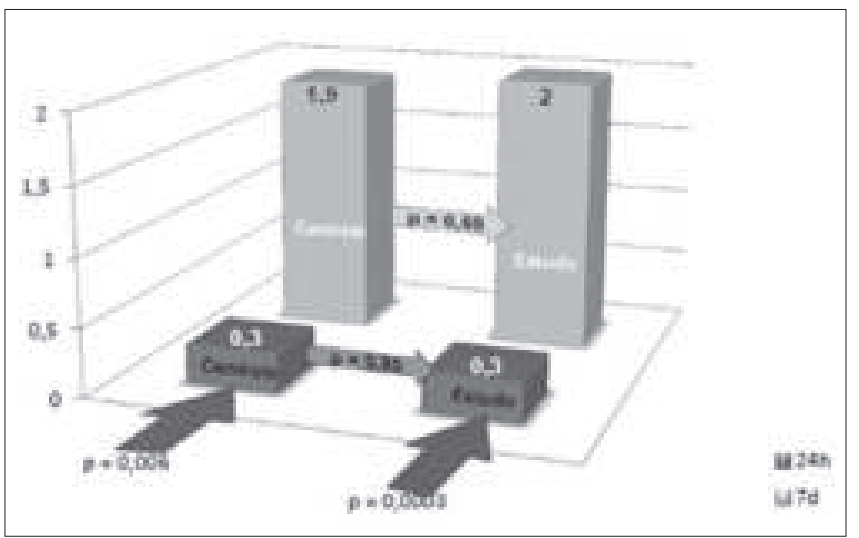

Figure 2 - Assessment of liver regeneration by mitotic index Statistical comparison between the study and control groups at the periods 24 hours (dark grey) and seven days (light grey). Statistical comparison between groups ( $p$ ). Mitotic index: number of nuclei in mitosis in ten high-power fields.

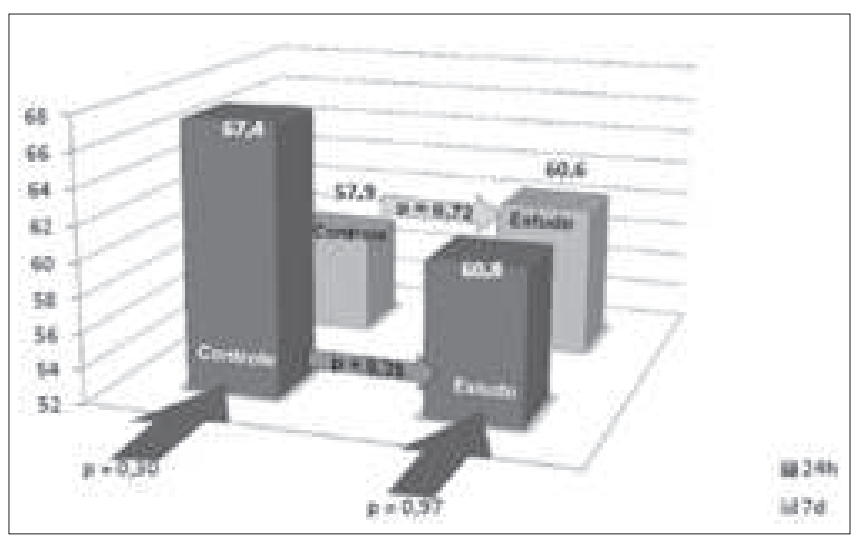

Figure 3 - Evaluation of the percentage of PCNA liver regeneration Statistical comparison between the study and control groups at the periods 24 hours (dark grey) and seven days (light grey). Statistical comparison between groups (p). PCNA: number of positive nuclei in 100 hepatocytes.

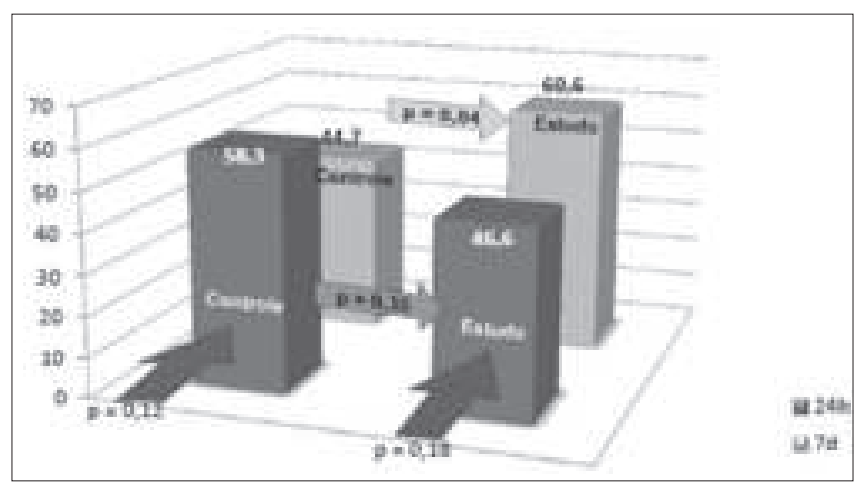

Figure 4 - Evaluation of the percentage of liver regeneration by Ki-67. Statistical comparison between the study and control groups at the periods 24 hours (dark grey) and seven days (light grey). Statistical comparison between groups (p). Ki-67: number of positive nuclei in 100 hepatocytes. in the absence of growth stimuli in the body, excluding general and specific mechanisms that could be inducing cell division activity in various tissues and organs.

In the study groups we used the pre-treatment with sirolimus since three days preceding the surgery until death of the animals within 24 hours or seven days after liver resection. The use of the pretreatment leads to the presence of sirolimus in the body at the time of hepatectomy, which is important to assess the influence of the drug on the minutes following hepatic resection. This strategy is crucial to the assessment of liver regeneration in rats, because the processes are initiated quickly, in minutes, and most fundamental changes are established within 24 hours. The oral route with a single daily dose was used because of its proven efficacy and bioavailability of the drug. The use of gavage allowed to have the guarantee of full-dose calculated for each animal.

The four subgroups showed a statistically significant decrease in body weight from the start of gavage until the date of death. This may be related to stress caused by handling of rats and surgical injuries suffered in the period. Comparisons between subgroups of 24 hours $\left(\mathrm{CG}_{24 \mathrm{~h}} \times \mathrm{SG}_{24 \mathrm{~h}}\right)$ and seven days $\left(\mathrm{CG}_{7 \mathrm{~d}} \times \mathrm{SG}_{7 \mathrm{~d}}\right)$ evaluating the average initial weight of hepatectomy and at the day of death rendered no statistically significant changes. These statistics show that there is no influence of the drug on weight gain in those groups.

When comparing the percentages of regeneration by the Kwon formula between each group, there was a significant increase in the rate of regeneration in the control $\left(\mathrm{CG}_{24 \mathrm{~h}} \times \mathrm{CG}_{7 \mathrm{~d}}\right)$ and study $\left(\mathrm{SG}_{24 \mathrm{~h}} \times \mathrm{SG}_{7 \mathrm{~d}}\right)$ ones over time. $\mathrm{CG}_{24 \mathrm{~h}}$ showed $60.72 \%$ regeneration and $\mathrm{CG}_{7 \mathrm{~d}^{\prime}} 83.61 \%(\mathrm{p}=$ 0.0001 ), while $\mathrm{SG}_{24 \mathrm{~h}}$ displayed $59.32 \%$, and $\mathrm{SG}_{7 \mathrm{~d}^{\prime}} 81.76 \%$ ( $p=0.0001$ ). G2 phase (mitosis) takes place in ${ }^{22-24}$ hours after liver resection, reaching a peak in 32-34 hours after the operation. Moreover, additional rounds of DNA synthesis can be detected days after partial hepatectomy, justifying the percentage increase of liver regeneration by the Kwon formula between the study and control groups 22-25. However, when comparing the 24-hour groups $\left(\mathrm{CG}_{24 \mathrm{~h}} \times \mathrm{SG}_{24 \mathrm{~h}}\right)$ and the seven-day ones $\left(\mathrm{CG}_{7 \mathrm{~d}} \times \mathrm{SG}_{7 \mathrm{~d}}\right)$, there was no statistically significant difference $(p=0.65$ and 0.70 , respectively). These data suggest no influence of sirolimus in the regenerative process when used as a parameter of the Kwon formula.

Statistical analysis of the mitotic index was significant only when the controls and study groups were compared with each other $(p=0.006$ and $p=0.0003$, respectively). When comparing the subgroups in the same period $\left(\mathrm{CG}_{24 \mathrm{~h}} \times \mathrm{SG}_{24 \mathrm{~h}}\right.$ and $\left.\mathrm{CG}_{7 \mathrm{~d}} \times \mathrm{SG}_{7 \mathrm{~d}}\right)$, there was no statistical difference. These data suggest no influence of sirolimus in liver regeneration when using the count of mitotic figures at $\mathrm{HE}$.

As for the PCNA analysis using the data between the subgroups in the same period $\left(\mathrm{CG}_{24 \mathrm{~h}} \times \mathrm{SG}_{24 \mathrm{~h}}\right.$ and $\left.\mathrm{CG}_{7 \mathrm{~d}} \times \mathrm{SG}_{7 \mathrm{~d}}\right)$ and between control and study groups 
$\left(\mathrm{CG}_{24 \mathrm{~h}} \times \mathrm{CG}_{7 \mathrm{~d}}\right.$ and $\left.\mathrm{SG}_{24 \mathrm{~h}} \times \mathrm{SG}_{7 \mathrm{~d}}\right)$, there was no statistically significant difference. These data are similar to the study by Chavez et al. ${ }^{26}$, which showed no interference in liver regeneration by sirolimus. When analyzing the control groups, comparing $\mathrm{CG}_{24 \mathrm{~h}} \times \mathrm{CG}_{7 \mathrm{~d}}$, there was a percentage decrease in PCNA positive hepatocytes with the time progression $(p=0.30)$. This decrease, even though not statistically significant, is due to the fact that the greater proliferation of hepatocytes occurs near the first 24 hours after hepatectomy. At the end of the seven days, the nuclei do not display the organized chromatin within an intact nuclear membrane and the product detected by immunohistochemistry disperses into the cytoplasm, avoiding its positivity. It should be noted that in the study group, when compared to 24-hour and the seven-day subgroups, we found a similar percentage of hepatocytes stained by PCNA ( $p=0.97)$.

When using the Ki-67 index (percentage of labeled cells / total analyzed cells), there was no significant difference between the two 24 hour subgroups $\left(\mathrm{CG}_{24 \mathrm{~h}} \times \mathrm{SG}_{24 \mathrm{~h}}\right)$. In the survey there was a statistically significant difference when compared the seven-day subgroups $\left(\mathrm{CG}_{7 \mathrm{~d}} \times \mathrm{SG}_{7 \mathrm{~d}}-\mathrm{p}=0.04\right)$. At the end of seven days of liver regeneration, the study group had a higher percentage of labeled hepatocytes when compared with the control group, demonstrating a greater number of hepatocytes in the group using sirolimus. This finding could suggest a stimulus on liver regeneration. Nevertheless, the peak of production of DNA followed by mitosis occurs early, and even if subsequent peaks take place, these are less severe and do not reflect a wide variation in regenerative percentage.

In the study by Palmes et al. ${ }^{27}$, with methods similar to ours, there was no statistical variation in the sevenday group when Ki-67 was used as a parameter. However, there was a statistically significant change in the analysis of the liver in the second, third and fourth days. This stimulation of cell proliferation in the liver, demonstrating an increased number of hepatocytes off the G0 period, may be related to the inhibition of natural killer cells during the regeneration process. According to Tamura et al. ${ }^{28}$, FK506 (tacrolimus) may promote liver regeneration by inhibiting the activity of natural killer cells. The same scenario could be applied to sirolimus, since it has a similar molecular structure ${ }^{29-31}$.

In this context, sirolimus, by inhibiting the activity of mTOR (Mammalian target of rapamycin) and its cell proliferation pathway, would also result in inhibition of the immune system. Decreased hepatolitic activity of natural killer cells by a summation effect would result in greater hepatic regeneration. When comparing the study subgroups $\left(\mathrm{SG}_{24 \mathrm{~h}} \times \mathrm{SG}_{7 \mathrm{~d}}\right)$ and the control ones $\left(\mathrm{CG}_{24 \mathrm{~h}} \times \mathrm{CG}_{7 \mathrm{~d}}\right)$ using Ki67 , there was no statistical difference $(p=0.18$ and $p=$ 0.12 , respectively).

By conducting this study, using parameters such as the weight of the regenerated liver, mitotic index and immunohistochemical analysis, there was no influence of sirolimus on liver regeneration in the groups studied, except in the analysis of Ki-67, which showed a positive influence.

\title{
R E S U M O
}

\begin{abstract}
Objetivo: avaliar a influência do sirolimo sobre a regeneração hepática desencadeada pela ressecção de $70 \%$ do fígado de ratos adultos. Métodos: utilizaram-se 40 ratos Wistar que foram divididos aleatoriamente em dois grupos (estudo e controle), cada grupo foi subdividido em dois subgrupos iguais conforme o dia da morte (24 horas e sete dias). O sirolimo foi administrado na dose de $1 \mathrm{mg} /$ $\mathrm{kg} / \mathrm{dia}$ no grupo de estudo e no grupo controle foi administrado $1 \mathrm{ml}$ de solução salina. As soluções foram administradas diariamente, desde três dias precedentes à hepatectomia até a morte dos ratos, para a retirada do fígado regenerado, realizada em $24 \mathrm{~h}$ ou $7 d$ após a hepatectomia. A análise da regeneração hepática foi mensurada pela fórmula de KWON, número de figuras de mitose pela técnica de hematoxilina-eosina e pelos marcadores imunoistoquímicos PCNA e Ki-67. Resultados: demonstrou-se variação estatisticamente significativa quando comparado os grupos $24 \mathrm{~h}$ com os grupos $7 d$ através dos métodos de análise. Ao comparar os grupos de estudo e controle no mesmo período demonstrou-se variação estatisticamente significativa apenas pelo Ki-67 no qual foi verificado aumento do número de hepatócitos em multiplicação celular no grupo de estudo de $7 d$ quando comparado com o grupo controle de $7 d(p=0,04)$. Conclusão: não demonstramos influência negativa do sirolimo na regeneração hepática e houve efeito parcial positivo pela análise imunoistoquímica utilizando Ki-67.
\end{abstract}

Descritores: Regeneração hepática. Sirolimo. Hepatectomia. Antígeno nuclear de célula em proliferação.

\section{REFERENCES}

1. Higgins GM, Anderson RM. Experimental pathology of the liver: Restoration of the liver by the white rat following partial surgical removal. Arch Pathol. 1931;12:186-202.

2. Court FG, Wemyss-Holden SA, Dennison AR, Maddern GJ. The mystery of liver regeneration. Br J Surg. 2002;89(9):1089-95.
3. Rozga J. Hepatocyte proliferation in health and in liver failure. Med Sci Monit. 2002;8(2):32-8.

4. Jesus RP, Waitzberg DL, Campos FG. Regeneração hepática: papel dos fatores de crescimento e nutrientes. Rev Assoc Med Bras. 2000:46(3):242-54.

5. Liu C, Schreiter T, Frilling A, Dahmen U, Broelsch CE, Gerken G, et al. Cyclosporine A, FK-506, 40-0-[2-hydroxyethyl] rapamycin and mycophenolate mofetil inhibit proliferation of human intrahepatic 
biliary epithelial cells in vitro. World J Gastroenterol 2005;11(948):7602-5.

6. Michalopoulos GK, DeFrances MC. Liver regeneration. Science. 1997;276(5309):60-6.

7. Michalopoulos GK. Liver regeneration: molecular mechanisms of growth control. FASEB J. 1990;4(2):176-87.

8. Tarlá MR, Ramalho FS, Ramalho LNZ, Silva TC, Brandão DF, Ferreira $J$, et al. A molecular view of liver regeneration. Acta Cir Bras. 2006:21(1):58-62.

9. Tarlá MR, Ramalho FS, Ramalho LNZ, Silva TC, Brandão DF, Ferreira $J$, et al. Cellular aspects of liver regeneration. Acta Cir Bras. 2006;21(1):63-6.

10. Fruman DA, Wood MA, Gjertson CK, Katz HR, Burakoff SJ, Bierer BE. FK506 binding protein 12 mediates sensitivity to both FK506 and rapamycin in murine mast cells. Eur J Immunol. 1995;25(2):56371.

11. Fausto N. Liver regeneration: from laboratory to clinic. Liver Transplant. 2001;7(10):835-44.

12. Ramalho FS, Ramalho LNZ, Zucoloto S, Silva Júnior OC. Regeneração hepatica: algumas definições num universo de incertezas. Acta Cir Bras. 1993;8(4):177-89.

13. Nelsen CJ, Rickheim DG, Tuckers MM, Hansen LK, Albrecht JH. Evidence that cyclin D1 Mediates both growth and proliferation downstream of TOR in hepatocytes. J Biol Chem. 2003;278(6):365663.

14. Watson CJE, Friend PJ, Jamieson NV, Frick TW, Alexander G, Gimson $A E$, et al. Sirolimus: a potent new immunosuppressant for liver transplantation. Transplantation. 2002;6(4):505-9.

15. Kwon AH. Effect of administration of fibonectin or aprotinin on liver regeneration after experimental hepatectomy. Ann Surg. 1990;211(3):295-300

16. Biondo-Simões MLP, Greca FH, Smaniotto GH, Techy F, Soares DP, Kannenberg $C$, et al. Efeito da histamina na regeneração hepática estudo experimental em ratos. Acta Cir Bras. 2000;15(1):350-6.

17. Assy N, Gong Y, Zhang M, Pettigrew NM, Pashniak D, Minuk GY. Use of proliferating cell nuclear antigen as a marker of liver regeneration after partial hepatectomy in rats. J Lab Clin Med. 1998;131(3):251-6.

18. Assy N, Minuk GY. Liver Regeneration: Methods for Monitoring their Aplications. J Hepatol. 1997;26(4):945-52.

19. Ben-izhak O, Bar-chana M, Sussman L, Dobiner V, Sandbank J. Ki67 antigen and PCNA proliferation markers predict survival in anorectal malignant melanoma. Histopathology. 2002:41(6):51925.
20. Bravo R, Frank R, Blundell PA, Bravo HM. Cyclin/PCNA is the auxiliary protein of DNA polymerase delta. Nature. 1987;326(6112):515-7.

21. Brown DC, Gatter KC. Ki-67 protein: the immaculate deception? Histopathology. 2002;40(1):2-11

22. Fausto N. Liver regeneration. J Hepatol. 2002;32(19):1477-87.

23. Michalopoulos GK. Liver regeneration. J Cell Physiol. 2007:213(2):286-300.

24. Koniaris LG, Mckillop I, Scwartz SI, Zimmers TA. Liver regeneration. J Am Col Surg. 2003;197(4):634-48.

25. LaBrecque D. Liver regeneration: a picture emerges from the puzzle. Am J Gastroenterol. 1994;89(8 Suppl):S86-96.

26. Cháves R, Jamieson N, Takamori S, Nivatvongs S, Pino G, Metcalfe A, et al. Hepatotrophic effect of cyclosporine and FK 506 is not mimicked by rapamycin. Transplant Proc. 1999;31(6):2429.

27. Palmes D, Zibert A, Budny T, Bahde R, Minin E, Kebschull L, et al. Impact of rapamycin on liver regeneration. Virchows Arch. 2008;452(5):545-57.

28. Tamura F, Masuhara A, Sakaida I, Fukumoto E, Nakamura T, Okita K. FK506 promotes liver regeneration by suppressing natural killer cell activity. J Gastroenterol Hepatol. 1998;13(7):703-8.

29. Francavilla A, Starzl TE, Carr B, Azzarone A, Carrieri G, Zeng Q, et al. The effects of FK 506, cyclosporine, and rapamycin on liver growth in vitro and in vivo. Transplant Proc. 1991;23(6):2817-20.

30. Francavilla A, Vujanovic NL, Polimeno L. Azzarone A, lacobellis A, Deleo $A$, et al. The in vivo effect of hepatotrophic factors augmenter of liver regeneration, hepatocyte growth factor, and insulin-like growth factor-II on liver natural killer cell functions. Hepatology. 1997;25(2):411-5.

31. Kirimlioglu H, Kirimlioglu V, Yilmaz S, Coban S, Turkmen E, Ara C. Liver pathology and cell proliferation after calcineurin inhibitors and antiproliferative drugs following partial hepatectomy in rats Transplant Proc. 2006;38(2):622-6.

Received on 15/06/2013

Accepted for publication 25/07/2013

Conflict of interest: none.

Source of funding: none.

Address for correspondence:

Edimar Leandro Toderke

E-mail: edimar.toderke@pucpr.br 